Article

\title{
Composition and Technological Properties of Clays for Structural Ceramics in Limpopo (South Africa)
}

\author{
Lawrence Diko-Makia * and Rofhiwa Ligege \\ Department of Mining and Environmental Geology, University of Venda, Private Bag X5050, \\ Thohoyandou 0950, Limpopo Province, South Africa; rofhione@gmail.com \\ * Correspondence: dikom73@gmail.com or diko.makia@univen.ac.za; Tel.: +27-015-960-8595
}

Received: 9 June 2020; Accepted: 2 July 2020; Published: 7 August 2020

\begin{abstract}
This study evaluated the potential of raw clays from the Mukondeni region for structural ceramics and pottery based on traditional firing techniques. Physical properties were identified by particle size distribution, consistency limits, and clay activity. Mineralogical and chemical properties were investigated by X-ray diffraction (XRD) and X-ray fluorescence (XRF). Extruded clay bodies were fired at $900{ }^{\circ} \mathrm{C}$. Technological characteristics were measured by weight loss (WL), bulk density (BD), dry linear shrinkage (DLS), fired linear shrinkage (FLS), water absorption (WA), and flexural strength (FS). The clays were low in $<2 \mu \mathrm{m}$ fractions $(\leq 19 \%)$ and of medium to high plasticity with a clayey silt texture. Smectite was the dominant clay mineral while quartz and feldspar were major non clay minerals. The most abundant oxides were $\mathrm{SiO}_{2}(63.57-68.73 \%), \mathrm{Al}_{2} \mathrm{O}_{3}(13.9-15.61 \%)$, and $\mathrm{Fe}_{2} \mathrm{O}_{3}$ (4.86-6.18\%), whereas $\mathrm{K}_{2} \mathrm{O}, \mathrm{CaO}, \mathrm{MgO}, \mathrm{Na}_{2} \mathrm{O}, \mathrm{TiO}_{2}$, and $\mathrm{P}_{2} \mathrm{O}_{5}$ were depleted. Characterization based on the clay workability chart, Winkler's diagram, and compositional ternary diagrams revealed acceptable extrusion properties and suitability for structural ceramics and earthenware. The clays showed acceptable WL, BD, LS, and WA, but unsatisfactory FS ( $\leq 1.08 \mathrm{MPa}$ ). Low mechanical strength was attributed to presence of smectites and inert nature of feldspar at $900{ }^{\circ} \mathrm{C}$. Beneficiation through mixing with carbonate-rich raw materials is recommended.
\end{abstract}

Keywords: structural ceramics; pottery; low firing temperature; fluxing agents; South Africa

\section{Introduction}

Natural clay (comprising clay minerals, silica, feldspar, and iron oxide) is the main raw material in the manufacture of traditional ceramics [1-4]. According to Teixera et al. [5] and Serra et al. [2], the exploitation of natural clays for various end-products, such as structural ceramics (bricks, roofing tile and blocks), and earthenware (household ceramics), is based on their availability, accessibility, and comparatively low to intermediate firing temperatures. The above attributes have been advanced as the base for socioeconomic development and sustainability of small-scale and artisanal clay mining sectors in developing economies [6]. The emphasis here is placed on lowering the cost of production, especially with regard to energy consumption, and the assertion that traditional kilns seldom fire at high temperatures above $900{ }^{\circ} \mathrm{C}[7-9]$.

Nonetheless, final product quality has been correlated with mechanical strength and water absorption capacity and shrinkage limits (volume and linear), which, in turn, depends on the sintering temperature [3,9-19]. Sintering temperature is considered one of the most important processing variables that influences final product costs [15]. During sintering, the clay body undergoes chemical and structural modifications that deeply transform the inherent characteristics of raw ceramic material. This process is accompanied by differential phase transformation and neo-mineral formation with resultant effect on technological properties $[4,6,17-26]$. Therefore, for optimal exploitation of natural clays, the sintering behavior needs to be fully appraised. 
In this study, we investigated the technological properties of two natural clays from South Africa (Mukondeni-Limpopo Province) for potential exploitation of structural ceramics and earthenware by artisanal clay miners. The temperature of $900{ }^{\circ} \mathrm{C}$ was selected as the suitable condition for the beginning of liquid phase sintering, increased material densification, and mechanical strength development in clay body (with exceptions at lower temperatures due to fluxing effect) $[4,10,11]$. It is anticipated that findings from this study will provide a basis to advise on raw material suitability and beneficiation where applicable.

\section{Materials and Methods}

Mukondeni is situated in Limpopo Province of South Africa, approximately $130 \mathrm{~km}$ from the provincial capital (Polokwane). The clay mine and pottery production is situated along the main road, about $300 \mathrm{~m}$ away from the settlement at coordinates $23^{\circ} 15^{\prime} 04^{\prime \prime} \mathrm{N}$ and $30^{\circ} 6^{\prime} 80^{\prime \prime} \mathrm{E}$ (Figure 1). Details of its physical geography and stratigraphy have been described elsewhere [27]. Geologically, the study site lies within the Southern marginal Zone (SMZ) of the Limpopo Belt. The approximately 60-k- wide ENE-WSW trending SMZ consists of granulite facies supracrustal gneisses of mafic, ultramafic, and metapelitic composition, intermixed with volumetrically dominant tonalitic grey gneiss. The metapelitic granulites consist of quartz, plagioclase, hypersthene, garnet, biotite and cordierite, with less common perthitic K-feldspar, spinel, sillimanite, and late kyanite [27]. The formations are largely described as supracrustal gneisses that have undergone a considerable degree of anatexis. Mineralogically, the grey gneisses comprise quartz, plagioclase, hornblende, and biotite [27].

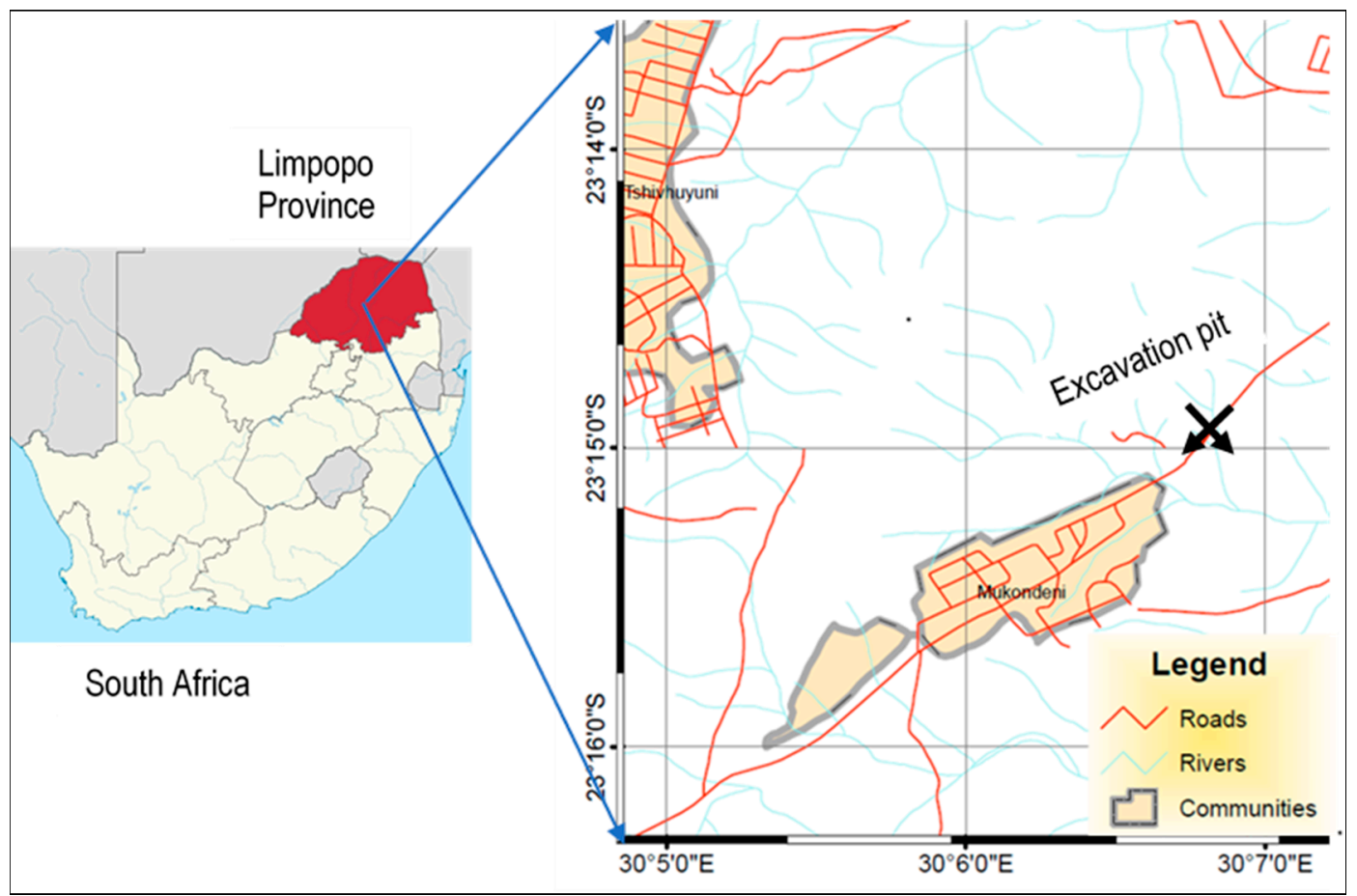

Figure 1. Location of study area; inset, situation of Limpopo in South Africa. (Modified from [27]).

Composite samples of clay labelled MK 1 and MK 2 from the main excavation pits in the study area were analyzed for particle size distribution (PSD), Atterberg limits (liquid limit, plastic limit, and plasticity index); clay activity (CA); mineralogy; chemical composition; and technological properties, namely weight loss (WL), bulk density (BD), water absorption (WA), linear shrinkage (DLS and FLS), and flexural strength (FS).

Particle size analysis by laser diffraction was performed with a Saturn DigiSizer 5200 (Council for Geoscience, Pretoria, South Africa). The samples were dispersed in a water medium to form a 
suspension of $0.00139 \mathrm{wt} \%$ solids and drawn into the size analyzer at a flow rate of $12.0 \mathrm{~L} / \mathrm{min}$ and circulation time of $120 \mathrm{~s}$. An in-house standard was used to validate particle dispersion. Atterberg limits were performed on the $<63 \mu \mathrm{m}$ fraction samples using the Casagrande apparatus [28]. For liquid limit (LL) determination, $40 \mathrm{~g}$ of previously prepared fine mortar was spread in a cup (maximum thickness $=1 \mathrm{~cm}$ ) and divided by a standard axial groove. The LL was expressed as a percentage by weight of the mortar after drying in an oven at $105^{\circ} \mathrm{C}$, at which the groove closed over a length of 1 $\mathrm{cm}$ under the influence of 25 blows. The blows were produced by allowing the cup to drop from a height of $1 \mathrm{~cm}$ onto a hard surface. In order to determine the limit of plasticity (PL), $10 \mathrm{~g}$ of the fine mortar was used. Using the palm, the mortar was rolled on a flat surface until the tread of fine mortar broke into sections of between $1 \mathrm{~cm}$ and $2 \mathrm{~cm}$ long, after being reduced to a diameter of $3 \mathrm{~mm}$. The PL was expressed as a percentage by weight after oven drying at $105^{\circ} \mathrm{C}$. The plasticity index (PI) was obtained from the arithmetic difference between LL and PL, whereas CA was calculated from the following expression:

$$
C A=P I / \text { clay } w t \%
$$

X-ray diffractometry was used for mineral identification. Prior to analysis, the samples were air-dried and gently ground with the aid of mortar and pestle into powdery form. Bulk and clay fractions obtained through pipette method) were mounted as oriented aggregates onto glass slides in a BRUKER D8 Advance diffractometer (Council for Geoscience, Pretoria, South Africa) equipped with a LYNXEYE detector and a Ni-filter. Powder mounts were scanned from $2^{\circ} 2 \theta \mathrm{CuK}$ to $70^{\circ}$ $2 \theta \mathrm{CuK}(\lambda=1.54060)$ radiation at a speed of $0.05^{\circ} 2 \theta$ steps size per second and generator settings of $40 \mathrm{kV}$ and $40 \mathrm{~mA}$. An overnight glycolation $(<24 \mathrm{~h})$ test was performed on the clay fraction to distinguish smectites from vermiculite [6]. Phase identification was based on BRUKER DIFFRAC Plus-EVA evaluation program (Council for Geoscience, Pretoria, South Africa). Phase concentrations were determined as semi quantitative estimates (with accuracy $\pm 5 \%$ ) using the Reference Intensity Ratio (RIR) method and relative peak heights/areas proportions [29].

The chemical composition of the bulk samples was determined by X-ray fluorescence spectrometry using a PANalytical Axios WDXRF spectrometer (Council for Geoscience, Pretoria, South Africa) equipped with a 4-kW Rh tube in accordance with the method described by the authors of [26]. Milled samples with grain size of $<75 \mu \mathrm{m}$ were heated at $1000{ }^{\circ} \mathrm{C}$ for $3 \mathrm{~h}$ to oxidize $\mathrm{Fe}^{2+}$ and $\mathrm{S}$ and to determine the loss on ignition (LOI). One gram of heated sample and $9 \mathrm{~g}$ of flux consisting of $34 \% \mathrm{LiBO}_{2}$ and $66 \%$ $\mathrm{Li}_{2} \mathrm{~B}_{4} \mathrm{O}_{7}$ were fused at $1050{ }^{\circ} \mathrm{C}$ to form stable glass disks. Each sample was analyzed three times, and the mean was recorded. For quality control, an in-house amphibolite reference material (12/76) was used to ensure accuracy of the data generated.

Technological tests were carried out at the Council for Mineral Technology (MINTEK, Johannesburg, South Africa), as part of the ceramic evaluation process. Clay samples were dried at $110{ }^{\circ} \mathrm{C}$ for $24 \mathrm{~h}$ and ground to a fine powder. The materials were mixed in a pan mixer with minimum quantity of water, suitable for extrusion in the Germatec Vacuum Extruder (Council for Geoscience, Pretoria, South Africa). Test briquettes were extruded into a column with a cross section measuring $47 \mathrm{~mm} \times 25 \mathrm{~mm} \times$ $150 \mathrm{~mm}$. The briquettes were air-dried for five days, followed by drying in a ventilated oven at $110^{\circ} \mathrm{C}$ for $24 \mathrm{~h}$ until two successive weighings at intervals of $2 \mathrm{~h}$ showed an increment of loss not greater than $0.2 \%$ of the previously determined weight of the specimen. After drying, the briquettes were cooled in a drying room maintained at a temperature of $24 \pm 8{ }^{\circ} \mathrm{C}$, with a relative humidity between $30 \%$ and $70 \%$. The specimens were stored free from drafts, unstacked, with separate placement, for a period of at least $4 \mathrm{~h}$ until the surface temperature was within $2.8^{\circ} \mathrm{C}$ of the drying room temperature. Specimens which were noticeably warm to the touch were not used for any tests $[6,16]$. The specimens were stored in the drying room at the required temperature and humidity until they were tested. The briquettes were fired at $900{ }^{\circ} \mathrm{C}$ using an electrically powered laboratory furnace at a heating rate of $80{ }^{\circ} \mathrm{C} / \mathrm{h}$ and cooling time of $2 \mathrm{~h}$. The fired specimens were tested for WL, BD, WA, LS, and FS. A total of five tests were performed per mechanical property and the mean result was reported. 
Weight loss (WL) was calculated between $105^{\circ} \mathrm{C}(\mathrm{Md})$ and peak firing temperatures (Mf) using the following formula:

$$
\mathrm{WL}(\%)=\left[\frac{\mathrm{Md}-\mathrm{Mf}}{\mathrm{Md}}\right] \times 100
$$

The bulk density (BD) of a specimen was obtained as the ratio of the fired specimen mass (Mf) to the measured volume $(\mathrm{V})$ of the specimen:

$$
\mathrm{BD}\left(\mathrm{g} / \mathrm{cm}^{3}\right)=\frac{\mathrm{Mf}}{\mathrm{V}}
$$

Water absorption (WA) was measured by weighing the dried briquette (M1) and the wet (M2) after immersion in water for $24 \mathrm{~h}$ :

$$
\mathrm{WA}(\%)=\frac{\mathrm{M} 2-\mathrm{M} 1}{\mathrm{M} 1} \times 100
$$

Dry and fired linear shrinkage (DLS and FLS) were determined across indentations made 100 $\mathrm{mm}$ apart by a digital Vernier caliper on the test briquettes. The dried/fired specimens were measured at the indentations to determine its longitudinal shrinkage to the nearest millimeter. The measured lengths were subtracted from the indentations, which were measured $100 \mathrm{~mm}$, to obtain the shrinkage in millimeters $[6,16]$.

The flexural strength (FS) of briquettes was evaluated using the three-point bending test method [6] using a Kingtest Auto 200 Press machine (Council for Geoscience, Pretoria, South Africa) at a loading rate of $20 \mathrm{~mm} / \mathrm{min}$. The modulus of rupture values of each specimen was calculated and reported to the nearest $0.01 \mathrm{MPa}$ as follows:

$$
\mathrm{FS}(\mathrm{MPa})=\frac{3 \mathrm{FL}}{2 \mathrm{~b} d^{2}}
$$

where $\mathrm{F}=$ maximum load, $\mathrm{L}=$ distance between the supports $(\mathrm{mm}), \mathrm{b}=$ net width of the specimen at the plane of failure (mm), and $d=$ depth of the specimen at the plane of failure $(\mathrm{mm})$.

\section{Results and Discussions}

\subsection{Physical Properties}

The PSD is important for determining suitability for various ceramic applications. PSD could be indicative of the drying and firing behavior of the raw material, as well as the mechanical strength of the fired product $[11,19,22]$ The results for PSD are summarized on Table 1 . Mk 1 and Mk 2 were low in clay fraction (18\% and 19\%), but high in $20-2 \mu \mathrm{m}$ fraction (48\% and $46 \%$ ) respectively. The raw materials were plotted on Winkler's diagram (Figure 2) in order to evaluate their suitable for different ceramic products $[11,16,19]$. Based on the PSD, MK 1 and Mk 2 were suitable raw materials for common bricks. This observation is consistent with grain size classification of raw ceramic materials from Cameroon [6,14,22], Morocco [16,30], and Turkey [4,31]. The predominance of silt-size fractions (comprising quartz and feldspar grains) suggest that PSD may contribute positively toward clay body skeleton, glass formation, and lowering of vitrification temperature [4,14].

Table 1. Physical properties of raw clay materials.

\begin{tabular}{cccccccc}
\hline \multirow{2}{*}{ Sample } & \multicolumn{3}{c}{ PSD (\%) } & \multicolumn{4}{c}{ Atterberg Limits (mass\%) } \\
\cline { 2 - 8 } & $\mathbf{2 0} \boldsymbol{\mu \mathbf { m }}$ & $\mathbf{2 0 - 2} \boldsymbol{\mu \mathbf { m }}$ & $<\mathbf{2} \boldsymbol{\mu \mathbf { m }}$ & LL & PL & PI & CA \\
\hline MK1 & 33 & 48 & 19 & 50.0 & 20.0 & 30.0 & 1.57 \\
MK2 & 36 & 46 & 18 & 41.8 & 16.0 & 25.8 & 1.43 \\
\hline
\end{tabular}




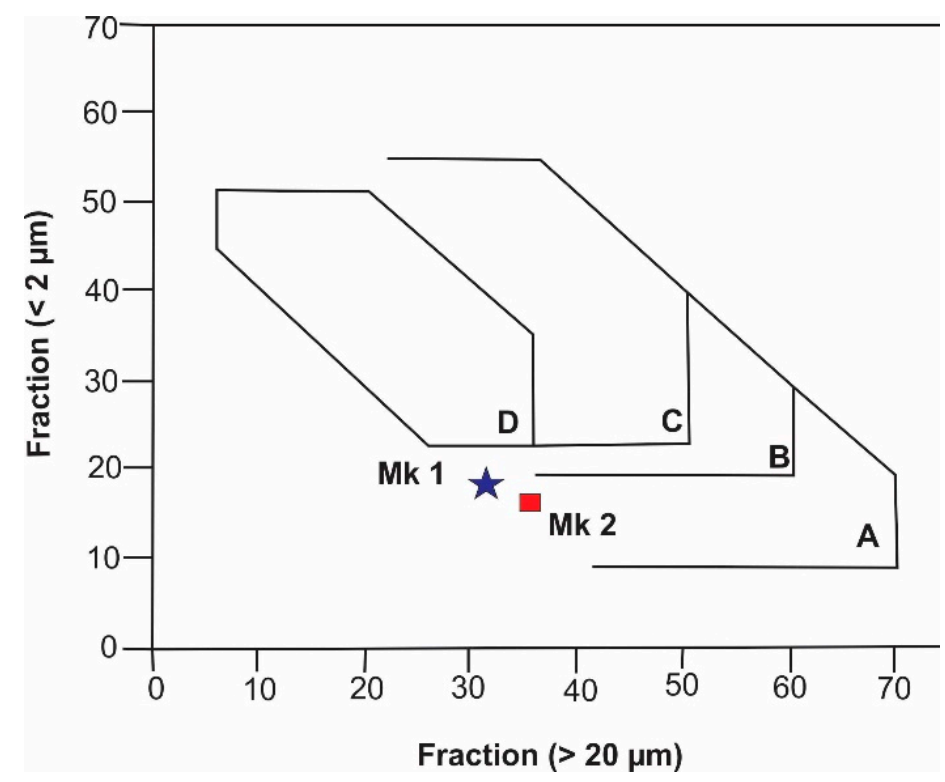

Figure 2. Grain size classification of raw clay materials according to Winkler's diagram [32]. Fields indicate: (A) Common bricks, (B) vertically perforated bricks, (C) roofing tiles and masonry bricks, and (D) hollow products.

Plasticity is an important parameter which assists in determining the clay workability, drying behavior, and ceramic application $[1,6,13,14,19,22,32]$. It is also an indicator of the major clay mineral phase in the raw material. The Atterberg limits and clay activity of MK 1 and MK 2 are presented on Table 1. Their consistency limits (PL, LL, and PI) were plotted on the Holtz and Kovacs diagram [33] (Figure 3a) and the clay workability chart [34] (Figure 3b). The raw materials were of medium to high plasticity ( $\mathrm{PI}=30$ and 25.8 for Mk 1 and Mk 2, respectively), with montmorillonite (smectite) as the major clay mineral. Mk 1 and Mk 2 plots were within the acceptable extrusion field, with MK 1 displaying a more sticky consistency than Mk 2 . This observation is consistent with their PI values.
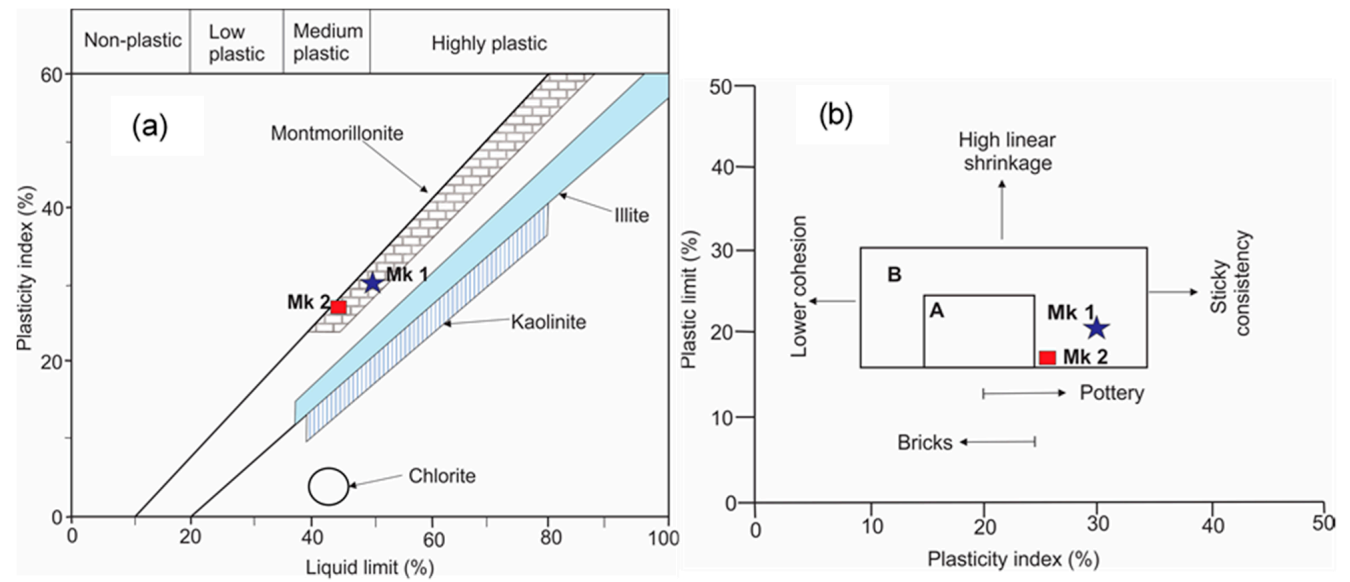

Figure 3. Consistency limits of raw clay materials: (a) According to Holtz and Kovacs diagram [33]; (b) clay workability chart [34].

Based on PL and PI, the raw materials were suitable for pottery. However, mixing them with low plastic clays enables exploitation for bricks. The CA values of Mk 1 and Mk 2 (1.57 and 1.43) were significantly lower than CA for pure smectite (7.2), but close to the values for calcic smectites (1.5) proposed by Temga et al. [22]. The CA values were nonetheless comparable to other smectitic raw materials from Cameroon, which are currently exploited for structural ceramics [19]. 


\subsection{Mineralogical Composition}

XRD patterns of bulk samples from ceramic raw materials are given in Figure 4. Table 2 presents a summary of the results of the mineral assemblages of the samples and the relative abundance of the respective minerals identified. The characteristic mineral assemblage comprised quartz, kaolinite, smectite, k-feldspar, plagioclase, talc, and amphibole. Smectite, identified at $15 \AA$, was the dominant clay mineral in both samples, accounting for $32 \%$ and $12 \%$ in MK 1 and Mk 2, respectively. Smectite was distinguished from vermiculite by a notable shift in d-spacing (17 $)$ after glycolation. Quartz $(31 \%$ and $52 \%$ ) and feldspar ( $28 \%$ and $24 \%$ ) were the major non clay minerals occurring in Mk 1 and 2 , respectively. The most prominent peaks were ascribed to quartz at $3.34 \AA$ due to abundant free silica [6,35], while the associated minor clay mineral phases (kaolinite at $7.17 \AA$ and talc at $9.31 \AA$ ) collectively contributed $6 \%$ and $5 \%$ to MK 1 and Mk 2, respectively.

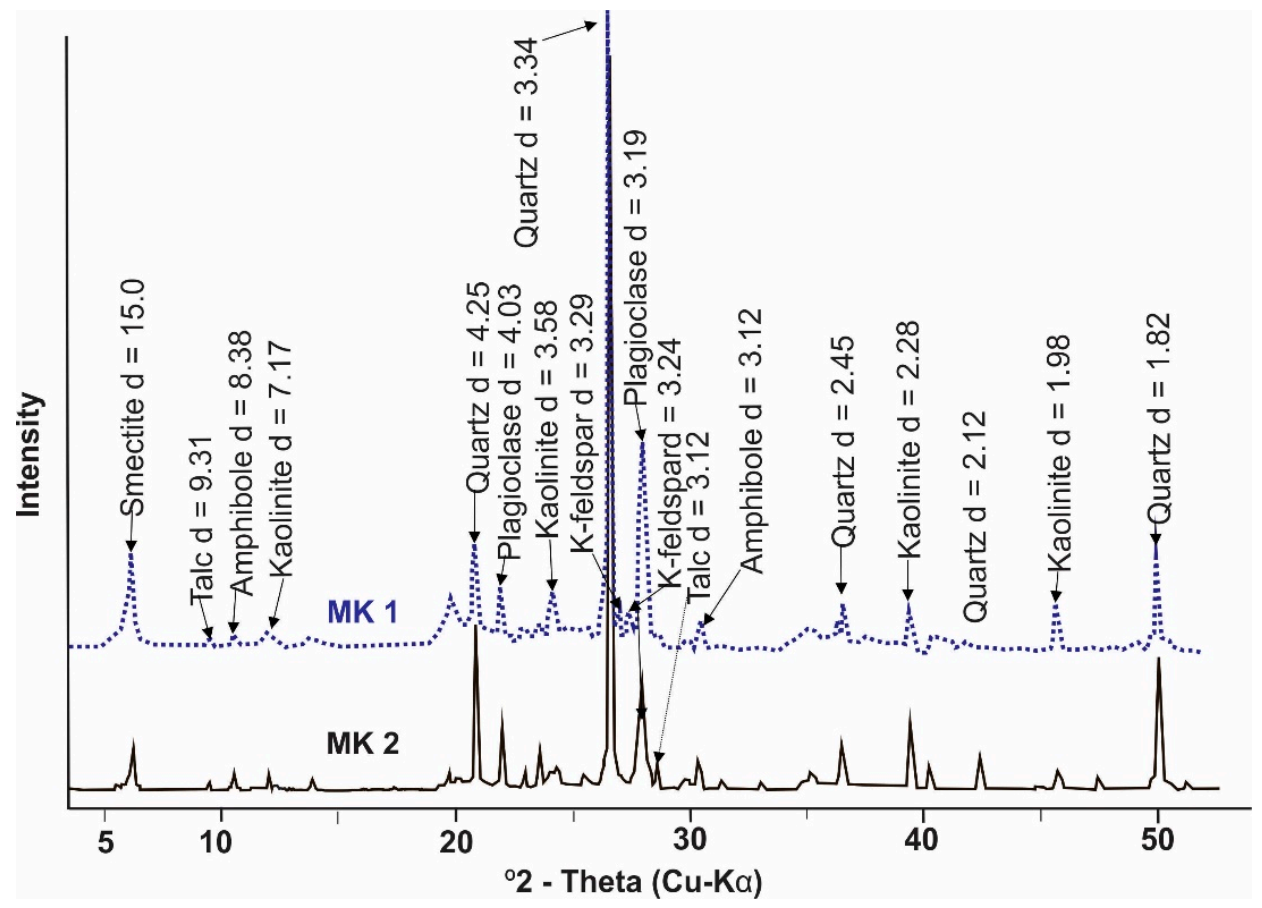

Figure 4. XRD patterns of raw clay materials.

Table 2. Mineralogical composition of raw clay materials (\%).

\begin{tabular}{cccccccc}
\hline Sample & K-feldspar & Plagioclase & Quartz & Talc & Smectite & Amphibole & Kaolinite \\
\hline MK1 & 2 & 26 & 31 & 2 & 32 & 3 & 4 \\
MK2 & 3 & 21 & 52 & 3 & 12 & 7 & 2 \\
\hline
\end{tabular}

The mineralogical constituents of ceramic pastes ranged from clay minerals as plastic and binder components to siliceous sand as skeletal components and finally feldspars and/or fine carbonates as fluxing agents. During the firing process, the main constituents of raw clay underwent phase transformations through decomposition to produce neo-mineralization, like metakaolinite and spinel at about $900{ }^{\circ} \mathrm{C}$ [11], as well as mullite, cristobalite, and wollastonite at higher temperatures [36,37]. The presence of smectite in the studied raw materials was expected to increase plasticity and impact the drying and swelling behavior and fired strength of the finished product. The non clay minerals, such as quartz and feldspar, enhance glass formation and densification at lower temperatures [22]. In order to determine the suitability of ceramic raw materials on the basis of mineralogical composition, the studied clays were plotted on the total clay-carbonate-quartz + feldspar ternary diagram (Figure 5a) proposed by Strazzera et al. [38] and applied to ceramic raw materials from southern Sardinia (Italy). 
The mineralogical compositions of $\mathrm{Mk} 1$ and $\mathrm{Mk} 2$ were equally compared against three major deposits of brick clays from Veneto (Wurman deposit,), Central Piedmont (Mindelian deposit), and Western Emilia-Ramagna (Rissian deposit) in Italy [39]. The latter three deposits are eluvial clays (fluvio-glacial deposits) enriched in quartz and smectite but deficient in dolomite and calcite [39], like the Mukondeni clays. Based on the comparison, Mk 1 was suitable for structural clay products, while Mk 2 plots were outliers (Figure 5a). This observation is consistent with clay consistency and PSD properties described earlier.
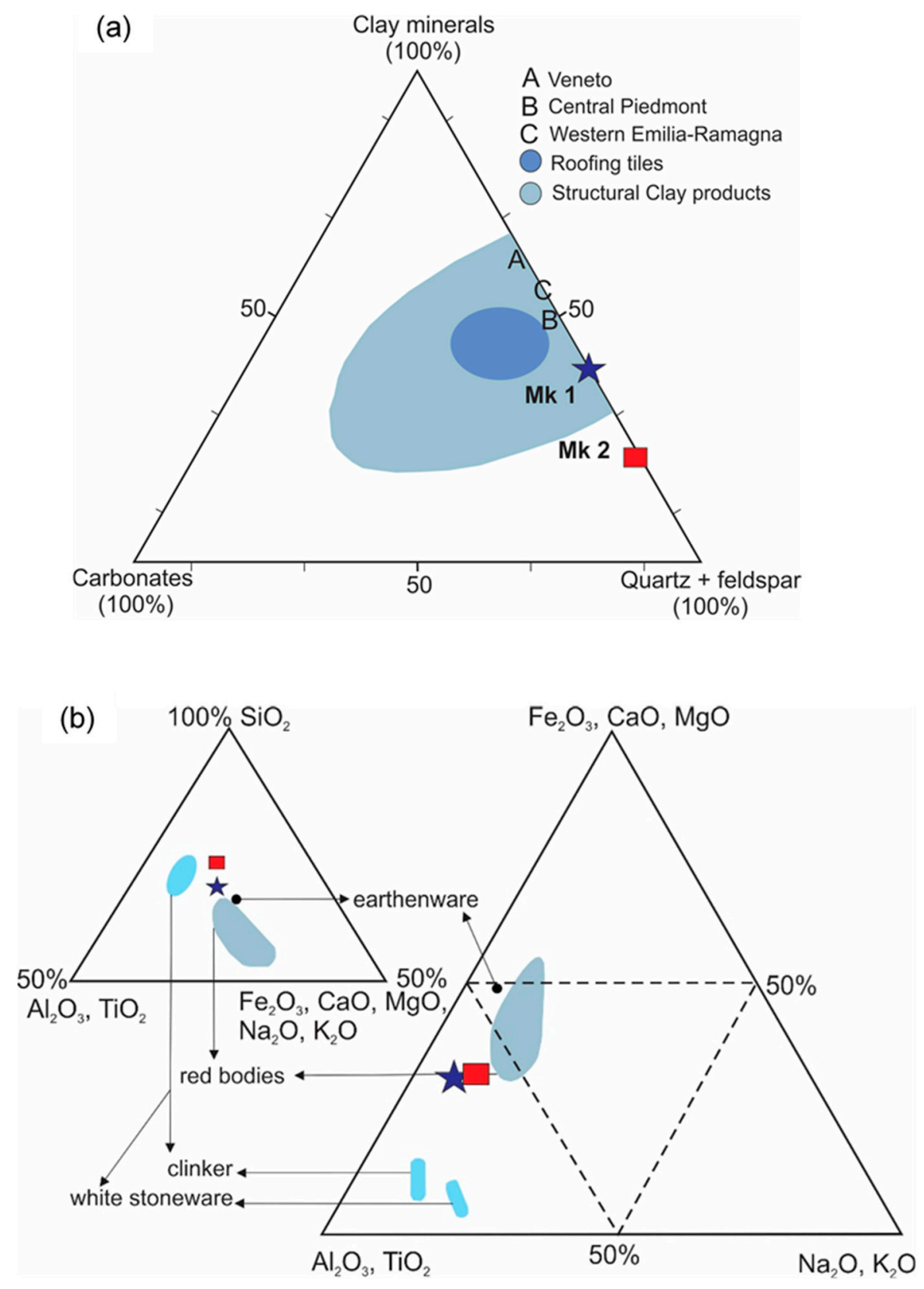

Figure 5. Mineralogical and geochemical classification of raw clay materials: (a) Clay, carbonate, quartz, and feldspar ternary diagram [38]; (b) major oxide content [40].

\subsection{Chemical Composition}

The chemical compositions of the bulk samples are given in Table 3. Their suitability as raw ceramic materials were assessed by comparing with the chemical compositions of Italian clays widely exploited for structural ceramics $[39,40]$. The most abundant oxides in Mk 1 and Mk 2 were $\mathrm{SiO}_{2}$ 
(63.57\% and 68.73\%), $\mathrm{Al}_{2} \mathrm{O}_{3}(15.61 \%$ and $13.9 \%)$, and $\mathrm{Fe}_{2} \mathrm{O}_{3}(6.18 \%$ and $4.86 \%)$, respectively, whereas $\mathrm{K}_{2} \mathrm{O}, \mathrm{CaO}, \mathrm{MgO}, \mathrm{Na}_{2} \mathrm{O}, \mathrm{TiO}_{2}$, and $\mathrm{P}_{2} \mathrm{O}_{5}$ were present only in small quantities. The LOI values were 5.08 for $\mathrm{Mk} 1$ and 3.29 for $\mathrm{Mk} 2$. In general fluxing agents, such as alkali oxides $\left(\mathrm{Na}_{2} \mathrm{O}\right.$ and $\left.\mathrm{K}_{2} \mathrm{O}\right)$ and alkaline earth oxides $(\mathrm{CaO}$ and $\mathrm{MgO})$ are low $(<3 \%)$, suggesting that it is unlikely that the densification of these clays is at $900{ }^{\circ} \mathrm{C}$. The presence of $\mathrm{Fe}_{2} \mathrm{O}_{3}$ and minor $\mathrm{TiO}_{2}$ corroborates classification of the studied clays as reddish yellow ceramics [41]. Loss on ignition values were related to the dehydroxylation of the clay minerals, organic matter oxidation, and decomposition of hydroxides [4,22]. The $\mathrm{SiO}_{2} / \mathrm{Al}_{2} \mathrm{O}_{3}$ ratios for $\mathrm{Mk} 1$ (4.0) and $\mathrm{Mk} 2$ (4.9) were significantly higher than the value generally found in pure kaolinite $\left(\mathrm{SiO}_{2} / \mathrm{Al}_{2} \mathrm{O}_{3}: 1.18\right)$ and montmorillonite $\left(\mathrm{SiO}_{2} / \mathrm{Al}_{2} \mathrm{O}_{3}: 2.36\right)$, but comparable to those reported in brick clays from Italy by Dondi et al. [39].

Table 3. Chemical composition (\%) of Mokundeni clays versus brick clays from Italy.

\begin{tabular}{|c|c|c|c|c|c|c|c|c|c|c|c|c|c|}
\hline Sample & $\mathrm{SiO}_{2}$ & $\mathrm{Al}_{2} \mathrm{O}_{3}$ & $\mathrm{Fe}_{2} \mathrm{O}_{3}$ & $\mathrm{CaO}$ & $\mathrm{K}_{2} \mathrm{O}$ & $\mathrm{MgO}$ & $\mathrm{Na}_{2} \mathrm{O}$ & $\mathrm{TiO}_{2}$ & $\mathrm{MnO}$ & $\mathrm{P}_{2} \mathrm{O}_{5}$ & LOI & Total & $\mathrm{Si} / \mathrm{Al}$ \\
\hline Mk 1 & 63.57 & 15.61 & 6.18 & 1.83 & 0.99 & 2.83 & 2.65 & 0.61 & 0.07 & 0.04 & 5.08 & 99.59 & 4.0 \\
\hline Mk 2 & 68.73 & 13.9 & 4.86 & 1.84 & 0.84 & 2.44 & 2.94 & 0.53 & 0.05 & 0.06 & 3.29 & 99.61 & 4.9 \\
\hline $\mathbf{A}(\mathrm{n}=5)$ & 60.3 & 18.5 & 6.7 & 0.8 & 3.9 & 2.0 & 0.6 & 0.9 & 0.1 & 0.2 & 6.5 & 99.0 & 3.3 \\
\hline $\mathbf{B}(\mathrm{n}=5)$ & 67.8 & 15.1 & 5.6 & 1.0 & 1.9 & 1.7 & 0.8 & 0.7 & 0.1 & 0.1 & 5.4 & 100.2 & 4.5 \\
\hline$C(n=3)$ & 67.8 & 15.3 & 5.6 & 1.0 & 1.9 & 1.7 & 1.0 & 0.8 & 0.2 & 0.1 & 5.2 & 100.6 & 4.4 \\
\hline
\end{tabular}

Italian brick clays: A (Veneto), B (Central Piedmont), and C (Western Emilia-Ramagna).

Further comparison with major oxide content used to classify ceramic raw materials from Sardinia (Figure 5b) by Fiori et al. [40] showed that Mk 1 and Mk 2 are very close outliers for earthenware and red clay body production. A $10 \%$ to $15 \%$ increase in $\mathrm{Al}_{2} \mathrm{O}_{3}$, alkali and alkali earth oxide contents would render the studied clays suitable for red bodies and earthenware (Figure 5b).

\subsection{Technological Properties}

A summary of the drying behavior (DLS) and firing characteristics (WL, BD, WA, FLS, and FS) of the studied clays after heat treatment at $900{ }^{\circ} \mathrm{C}$ is presented on Table 4 . The mean values of test results $(n=5)$ for Mk 1 and Mk 2, respectively, were: DLS (5.67\% and 5.0\%), WL (11.37\% and 8.65\%), Bd $\left(1.72 \mathrm{~g} / \mathrm{cm}^{3}\right.$ and $\left.1.77 \mathrm{~g} / \mathrm{cm}^{3}\right)$, WA $(12.58 \%$ and $11.70 \%)$, LS (7.0\% and 5.72\%), and FS (1.08 and 0.87 MPa).

Table 4. Firing characteristics of raw clay materials.

\begin{tabular}{cccccccc}
\hline Sample & \multicolumn{2}{c}{ Characteristics T1 } & T2 & T3 & T4 & T5 & Mean \\
\hline \multirow{5}{*}{ MK 1 } & WL $(\%)$ & 16.06 & 12.40 & 8.34 & 8.33 & 11.71 & 11.37 \\
& BD $\left(\mathrm{g} / \mathrm{cm}^{3}\right)$ & 1.72 & 1.71 & 1.72 & 1.72 & 1.72 & 1.72 \\
& WA (\%) & 12.75 & 12.73 & 11.99 & 12.59 & 12.82 & 12.58 \\
& FLS (\%) & 7.50 & 7.74 & 5.79 & 7.08 & 6.90 & 7.00 \\
& FS (MPa) & 1 & 1.09 & 1.11 & 1.1 & 1.11 & 1.08 \\
& DLS (\%) & 5.02 & 5.84 & 5.33 & 6.5 & 5.67 & 5.67 \\
\hline \multirow{5}{*}{ MK 2 } & WL (\%) & 10.87 & 8.36 & 9.07 & 7.94 & 7.03 & 8.65 \\
& BD (g/cm $\left.{ }^{3}\right)$ & 1.78 & 1.77 & 1.78 & 1.77 & 1.78 & 1.77 \\
& WA (\%) & 11.55 & 11.88 & 11.54 & 11.51 & 12.02 & 11.70 \\
& LS (\%) & 6.00 & 5.65 & 5.59 & 5.33 & 6.01 & 5.72 \\
& FS (MPa) & 0.77 & 0.94 & 0.87 & 0.88 & 0.89 & 0.87 \\
& DLS (\%) & 4.93 & 4.85 & 4.76 & 4.83 & 5.63 & 5.00 \\
\hline
\end{tabular}

Weight loss (WL), Bulk density (BD), Water absorption (WA), Fired linear shrinkage (FLS), Flexural strength (FS), Dry linear shrinkage (DLS), and $\mathrm{T}$ (number of tests).

In order to appraise the technological performance of $\mathrm{Mk} 1$ and $\mathrm{Mk} 2$ after firing, we compared them against ceramic specifications based on WL [5], LS [4], FS, and WA [5,42]. According to Yongue-Fouateu et al. [6], values for LS (2-10\%), WA (8.03-24.27\%), and FS (1.2-11.8 MPa) have frequently been used as quality and process control parameters in the development and manufacturing 
stages to produce structural ceramics. The studied clays registered WL below the $14 \%$ threshold [5], suggesting low organic matter content. LS for Mk 1 (7\%) and Mk 2 (5.72\%) fell within the range suggested by Yongue-Fouateu et al. [6], but Mk 2 was lower than the $7-10 \%$ range prescribed by Manukaji [36] and Semiz [4]. Ceramic specifications according to FS and WA are presented on Table 5. The WA of the studied clays were suitable for massive bricks, ceramic blocks, and even roof tiles, whereas FS were significantly lower than values reported for Italian brick clays by Dondi et al. [43]. Based on FS, Mk 1 and Mk 2 were unsuitable for any ceramic piece at the current firing temperature.

Table 5. Ceramic specifications based on flexural strength and water absorption $[5,42,43]$.

\begin{tabular}{|c|c|c|c|c|c|c|c|c|c|}
\hline \multirow{2}{*}{ Ceramic Piece } & \multicolumn{6}{|c|}{ Flexural Strength (MPa) } & \multicolumn{3}{|c|}{ Water Absorption (\%) } \\
\hline & $\begin{array}{l}\text { Indicated } \\
\text { Values }\end{array}$ & $\begin{array}{c}\mathrm{A} \\
(n=5)\end{array}$ & $\begin{array}{c}\text { B } \\
(n,=; 5)\end{array}$ & $\begin{array}{c}\mathrm{C} \\
(n=3)\end{array}$ & $\begin{array}{l}\text { Mk 1 } \\
(1.08)\end{array}$ & $\begin{array}{l}\text { Mk } 2 \\
(0.87)\end{array}$ & $\begin{array}{l}\text { Indicated } \\
\text { Values }\end{array}$ & $\begin{array}{c}\text { Mk 1 } \\
(12.58)\end{array}$ & $\begin{array}{c}\text { Mk 2 } \\
(11.70)\end{array}$ \\
\hline Not classified & $<1.96$ & - & - & - & $\sqrt{ }$ & $\sqrt{ }$ & - & & \\
\hline Massive bricks & $\geq 1.96$ & $6 \pm 2$ & $6 \pm 2$ & $8 \pm 2$ & - & - & $\leq 25$ & $\sqrt{ }$ & $\sqrt{ }$ \\
\hline Ceramic blocks & $\geq 5.39$ & $6 \pm 2$ & $6 \pm 2$ & $8 \pm 2$ & - & - & $\leq 25$ & $\sqrt{ }$ & $\sqrt{ }$ \\
\hline Roof tiles & $\geq 6.37$ & $12 \pm 2$ & $14 \pm 2$ & - & - & - & $\leq 20$ & $\sqrt{ }$ & $\sqrt{ }$ \\
\hline
\end{tabular}

Italian brick clays: A (Veneto), B (Central Piedmont), and C (Western Emilia-Ramagna).

\section{Conclusions}

This study investigated the suitability of two raw clay materials from the Mukondeni region (South Africa) for structural ceramics and earthenware, after firing at $900{ }^{\circ} \mathrm{C}$. The following conclusions can be deduced from the physical, mineralogical, chemical, and technological characteristics of the raw materials:

- The predominance of smectite contributes to the high DLS and FLS observed. This also resulted in the development of cracks on ceramic bodies after dry processing and the increase in apparent porosity.

- Mechanically, the raw clays showed acceptable WL (11.37\% and 8.65\%), BD (1.72 and $\left.1.77 \mathrm{~g} / \mathrm{cm}^{3}\right)$, and WA (12.58\% and $11.70 \%)$, but unsatisfactory FS ( $\leq 1.08 \mathrm{MPa})$. Low mechanical strength was attributed to the fact that feldspars (though in high percentage) remained substantially inert at $900{ }^{\circ} \mathrm{C}$.

- Beneficiation through mixing with carbonate-rich raw materials may enhance fluxing effects and improve mechanical strength of clay bodies at $900{ }^{\circ} \mathrm{C}$. Mixture with low plasticity clays is also recommended.

Author Contributions: Conceptualization, L.D.-M.; methodology, L.D.-M.; formal analysis, L.D.-M. and R.L.; investigation, R.L.; writing —original draft preparation, R.L.; writing—review and editing, L.D.-M.; supervision, L.D.-M.; funding acquisition, L.D.-M. All authors have read and agree to the published version of the manuscript.

Funding: Incentive Funding for Rated Researchers by National Research Foundation (NRF), South Africa (UID109316) is acknowledge.

Conflicts of Interest: The authors declare no conflict of interest.

\section{References}

1. Murray, H.H. Applied Clay Mineralogy: Occurrences, Processing and Application of Kaolins, Bentonites, Palygorskite-Sepiolite and Common Clays: Developments in Clay Science; Elsevier: Amsterdam, The Netherlands, 2007; Volume 2, p. 179.

2. Serra, M.F.; Conconi, M.S.; Suarez, G.; Agietti, E.F.; Rendtorff, N.M. Firing transformations of an argentinean calcareous commercial clay. Cerâmica 2013, 59, 254-261. [CrossRef]

3. Hamisi, H. Influence of Firing Temperature on Physical Properties of Same Clay and Pugu Kaolin for Ceramic Tiles Application. Int. J. mater. Sci. Appl. 2014, 3, 143-146. [CrossRef]

4. Semiz, B. Characteristics of clay-rich raw materials for ceramic applications in Denizli region (Western Anatolia). Appl. Clay Sci. 2017, 137, 83-93. [CrossRef] 
5. Teixera, S.R.; Souza, S.A.; Moura, C.A. Mineralogical characterization of clays used in the structural ceramic industry in West of Sao Paulo State, Brazil. Cerâmica 2001, 47, 204-207. [CrossRef]

6. Yongue-Fouateu, R.; Ndimukong, F.; Njoya, A.; Kunyukubundo, F.; Mbih, P.K. The Ndop plain clayey materials (Bamenda area-NW Cameroon): Mineralogical, geochemical, physical characteristics and properties of their fired products. J. Asian Ceram. Soc. 2016, 4, 299-308. [CrossRef]

7. El Halim, M.; Daoudi, L.; El Ouahabi, M.; Amakrane, J.; Fagel, N. Mineralogy and firing characteristics of clayey materials used for ceramic purposes from Sale region (Morocco). J. mater. Environ. Sci. 2018, 9, 2263-2273.

8. Grifa, C.; Germinario, C.; De De Bonis, A.; Mercurio, M.; Izzo, F.; Pepe, F.; Bareschino, P.; Cucciniello, C.; Monetti, V.; Morra, V.; et al. Traditional brick productions in madagascar: From raw material processing to firing technology. Appl. Clay Sci. 2017, 150, 252-266. [CrossRef]

9. Martín-Márquez, J.; Rincón, J.M.; Romero, M. Effect of firing temperature on sintering of porcelain stoneware tiles. Ceram. Int. 2008, 34, 1867-1873. [CrossRef]

10. El Ouahabi, M.; El Idrissi, H.E.B.; Daoudi, L.; El Halim, M.; Fagel, N. Moroccan clay deposits: Physico-chemical properties in view of provenance studies on ancient ceramics. Appl. Clay Sci. 2019, 172, 65-74. [CrossRef]

11. Aramide, F.O. Effect of Firing Temperature on Mechanical Properties of Fired masonry Bricks Produced from Ipetumodu Clay. Leonardo J. Sci. 2012, 21, 70-80.

12. Baccour, H.; Medhioub, M.; Jamoussi, F.; Mhiri, T. Influence of firing temperature on the ceramic properties of Triassic clays from Tunisia. J. mater. Process. Technol. 2009, 209, 2812-2817. [CrossRef]

13. Ngun, B.K.; Mohamad, H.; Sulaiman, S.K.; Okada, K.; Ahmad, Z. Some ceramic properties of clays from central Cambodia. Appl. Clay Sci. 2011, 53, 33-41. [CrossRef]

14. Diko, M.L.; Ekosse, G.I.; Ayonghe, S.; Ntasin, E. Physical characterization of clayey materials from tertiary volcanic cones in Limbe (Cameroon) for ceramic applications. Appl. Clay Sci. 2011, 51, 380-384. [CrossRef]

15. Serra, M.F.; Acebedo, M.F.; Conconi, M.S.; Suarez, G.; Aglietti, E.F.; Rendtorff, N.M. Thermal evolution of the mechanical properties of calcareous earthenware. Ceram. Int. 2014, 40, 1709-1716. [CrossRef]

16. Lahcen, D.; Hicham, E.E.; Latifa, S.; Abderrahmane, A.; Jamal, B.; Mohamed, W.; Meriam, E.; Nathalie, F. Characteristics and ceramic properties of clayey materials from Amezmiz region (Western High Atlas, Morocco). Appl. Clay Sci. 2014, 102, 139-147. [CrossRef]

17. Peng, L.; Qin, S. Sintering Behavior and Technological Properties of Low-Temperature Porcelain Tiles Prepared Using a Lithium Ore and Silica Crucible Waste. Minerals 2019, 9, 731. [CrossRef]

18. Joseph-Marie, M.; Raunel, L.; Timothée, N.; Mozalin, F.P. Characterization and technological properties of two clay soils in Republic of Congo. Res. J. mater. Sci. 2019, 7, 1-10.

19. Temga, J.P.; Mache, J.R.; Madi, A.B.; Nguetnkam, J.P.; Bitom, D.L. Ceramics applications of clay in Lake Chad Basin, Central Africa. Appl. Clay Sci. 2019, 171, 118-132. [CrossRef]

20. Baioumy, H.M.; Ismael, I.S. Composition, origin and industrial suitability of the Aswan ball clays, Egypt. Appl. Clay Sci. 2014, 102, 202-212. [CrossRef]

21. Boulingui, J.; Nkoumbou, C.; Njoya, D.; Thomas, F.; Yvon, J. Characterization of clays from Mezafe and Mengono (Ne-Libreville, Gabon) for potential uses in fired products. Appl. Clay Sci. 2015, 115, 132-144. [CrossRef]

22. Boussen, S.; Sghaier, D.; Chaabani, F.; Jamoussi, B.; Bennour, A. Characteristics and industrial application of the Lower Cretaceous clay deposits (Bouhedma Formation), Southeast Tunisia: Potential use for the manufacturing of ceramic tiles and bricks. Appl. Clay Sci. 2016, 123, 210-221. [CrossRef]

23. Pardo, F.; Jordán, M.M.; Montero, M. Ceramic behaviour of clays in Central Chile. Appl. Clay Sci. 2018, 157, 158-164. [CrossRef]

24. González, I.; Romero-Baena, A.; Galán, E.; Miras, A.; Castilla-Alcántara, J.C.; Campos, P. Ceramic materials from Cuatrovitas archaelogical site (Spain). A mineralogical and chemical study for determining the provenance and the firing temperature. Appl. Clay Sci. 2018, 166, 38-48. [CrossRef]

25. Hradil, D.; Hradilová, J.; Holcová, K.; Bezdička, P. The use of pottery clay for canvas priming in Italian Baroque-An example of technology transfer. Appl. Clay Sci. 2018, 165, 135-147. [CrossRef]

26. Viani, A.; Cultrone, G.; Sotiriadis, K.; Ševčík, R.; Sasek, P. The use of mineralogical indicators for the assessment of firing temperature in fired-clay bodies. Appl. Clay Sci. 2018, 163, 108-118. [CrossRef]

27. Amponsah-Dacosta, F.; Muzerengi, C.; Mhlongo, S.E.; Mukwevho, G.F. Characterization of clays for making ceramic pots and water filters at Mukondeni village, Limpopo province, South Africa. ARPN J. Eng. Appl. Sci. 2013, 8, 927-932. 
28. Diko, M.L.; Banyini, S.C.; Monareng, B.F. Landslide susceptibility on selected slopes in Dzanani, Limpopo Province, South Africa. Jàmbá J. Disaster Risk Stud. 2014, 6, 1-7. [CrossRef]

29. Ekosse, G.E.; Ngole-Jeme, V.M.; Diko, M.L. Environmental Geochemistry of Geophagic materials from Free State Province in South Africa. Open Geosci. 2017, 9, 114-125. [CrossRef]

30. El Ouahabi, M.; Daoudi, L.; Fagel, N. Mineralogical and geotechnical characterization of clays from northern Morocco for their potential use in the ceramic industry. Clay Miner. 2014, 49, 35-51. [CrossRef]

31. Celik, H. Technological characterization and industrial application of two Turkish clays for the ceramic industry. Appl. Clay Sci. 2010, 50, 245-254. [CrossRef]

32. Winkler, H.G.F. Bedeutung der Korngrössenverteilung und des Mineralbestandes von Tonen für die Herstellung grobkeramischer Erzeugnisse. Ber. Dtsch. Keram. Ges. 1954, 31, 337-343.

33. Holtz, R.D.; Kovacs, W.D. An Introduction to Geotechnical Engineering; Prentice-Hall, Inc.: New Jersey, NY, USA, 1981; p. 733.

34. Marsigli, M.; Dondi, M. Plasticita delle Argille Italiane per Laterizi e Previsione Del Loro Comportamento in Foggiatura. L'industria Laterizi 1997, 46, 214-222.

35. Vieira, C.M.F.; Sanchez, R.; Monteiro, S. Characteristics of clays and properties of building ceramics in the state of Rio de Janeiro, Brazil. Constr. Build. mater. 2008, 22, 781-787. [CrossRef]

36. Manukaji, J.U. Chemical and mechanical characterization of clay samples from Kaduna State Nigeria. Int. J. Eng. Invent. 2013, 7, 20-26.

37. El Idrissi, H.E.B.; Daoudi, L.; El Ouahabi, M.; Collin, F.; Fagel, N. The influence of clay composition and lithology on the industrial potential of earthenware. Constr. Build. mater. 2018, 172, 650-659. [CrossRef]

38. Strazzera, B.; Dondi, M.; Marsigli, M. Composition and ceramic properties of tertiary clays from southern Sardinia (Italy). Appl. Clay Sci. 1997, 12, 247-266. [CrossRef]

39. Dondi, M.; Ercolani, G.; Fabbri, B.; Guarini, G.; Marsigli, M.; Mingazzini, C. major deposits of brick clays in Italy, Part 1: Geology and composition. Tile Brick Int. 1999, 15, 230-237.

40. Fiori, C.; Fabbri, B.; Donati, G.; Venturi, I. Mineralogical composition of the clay bodies used in the Italian tile industry. Appl. Clay Sci. 1989, 4, 461-473. [CrossRef]

41. De Bonis, A.; Cultrone, G.; Grifa, C.; Langella, A.; Leone, A.P.; Mercurio, M.; Morra, V. Different shades of red: The complexity of mineralogical and physico-chemical factors influencing the colour of ceramics. Ceram. Int. 2017, 43, 8065-8074. [CrossRef]

42. Souza, G.P.; Sanchez, R.; Holanda, J.N.F. Characteristics and physical-mechanical properties of fired kaolinitic materials. Cerâmica 2002, 48, 102-107. [CrossRef]

43. Dondi, M.; Ercolani, G.; Fabbri, B.; Guarini, G.; Marsigli, M.; Mingazzini, C. Major deposits of brick clays in Italy, Part 2: Technological properties and uses. Tile Brick Int. 1999, 15, 360-371. 